${ }^{1}$ Institute of Radio Astronomy, National Academy of Sciences of Ukraine, Kharkiv, 61002, Ukraine

${ }^{2}$ Space Research Centre of Polish Academy of Sciences, Warsaw, 00-716, Poland

${ }^{3}$ State Institution National Antarctic Scientific Center, Ministry of Education and Science of Ukraine, Kyiv, 01601, Ukraine

*Corresponding author: zaliz@rian.kharkov.ua

\title{
Variability of Weddell Sea ionospheric anomaly as deduced from observations at the Akademik Vernadsky station
}

\begin{abstract}
Ionospheric Weddell Sea anomaly is an inversion of diurnal variation of the electron density in the ionosphere over Antarctic Peninsula, Weddell Sea, and neighbor territories observed during Antarctic summer. This paper aims at analyzing the reaction of the ionosphere during the Weddell Sea anomaly to changes in solar and geomagnetic activity as deduced from the data of vertical sounding of the ionosphere conducted at the Akademik Vernadsky station. The aim is achieved by comparing the monthly median values of the critical frequencies of the ionosphere (foF2) during Weddell Sea anomaly for the years of high and low solar activity; as well as by comparison of median December height-time diagrams (HT-diagrams) of foF2 calculated separately for the time intervals characterized by low or high levels of F10.7 and K indices for the period from 2007 till 2016. It was experimentally demonstrated that the Weddell Sea anomaly depends on the levels of solar ultraviolet flux and local K indices. The biggest nighttime maximum of ionization corresponds to low $\mathrm{K}$ indices and high values of F10.7. The most accurate inversion of diurnal variation of electron density in the F region is observed under the low values of K index and low F10.7 flux. The growth of geomagnetic activity decreases the nighttime ionization under both low and high levels of F10.7 fluxes and leads to a blur of the night maximum. Visible virtual heights of maximums increase together with F10.7 independently of the K index level. Blurring of the night maximum can be explained by destruction of the field of thermospheric winds supporting the nighttime anomaly, and/or by increasing role of plasma drifts in comparison with wind impact. The growth of visible virtual height of the nighttime maximum with increasing solar F10.7 flux could be explained by the gain of equatorward thermospheric wind with increasing solar ultraviolet flux that leads to growth of plasma upwelling effect. The Doppler frequency shift of the signals reflected from the ionosphere during nighttime in presence of the Weddell Sea anomaly is close to zero which could be explained by a stable F2 layer formed as a result of dynamic equilibrium between photochemical processes and upward plasma transport.
\end{abstract}

Keywords: ionosphere, ionogram, Weddell Sea anomaly, median height-time diagram

\section{Introduction}

In the late 1950 s, it was discovered that according to the data of the vertical sounding of the ionosphere by ionosonde located in Halley Bay $\left(75.6^{\circ} \mathrm{S}, 26.6^{\circ} \mathrm{W}\right)$, in summer the values of the critical frequency of the F2 layer (foF2) at midnight exceed the midday values
(Bellchambers \& Piggott, 1958). The effect was called the Weddell Sea anomaly (WSA) because the ionosonde was located on the coast of this sea. Although the first information on the inversion of the diurnal variation of the critical frequencies of the ionosphere was published according to the Halley ionosonde, further measurements and comparisons showed that 
the WSA is most pronounced at the Argentine Islands Archipelago located off the western coast of the Antarctic Peninsula. Ukrainian Antarctic Akademik Vernadsky station (until 1996 it was British Faraday base) is operating at that Archipelago. Continuous vertical sounding of the ionosphere at the FaradayAkademik Vernadsky station $\left(65^{\circ} 15^{\prime} \mathrm{S}, 64^{\circ} 16^{\prime} \mathrm{W}\right)$ has been carried out there since the late 1950s as well.

The role of the thermospheric winds as the main driver of the anomaly has been explained a long time ago, for the first time, probably, in (Kohl \& King, 1967). The Weddell Sea anomaly is maybe the brightest example demonstrating how the dynamics of the neutral atmosphere can affect the main parameters of the near-Earth plasma.

In recent years, the morphology of the anomaly is studied mostly using satellite techniques and data (Chang et al., 2015; Zakharenkova et al., 2017). Measurements of the total electron content carried out within TOPEX/Poseidon experiment showed that WSA is expressed in the range of longitudes from $200^{\circ}$ to $300^{\circ} \mathrm{E}$ (Horvath \& Essex, 2003). Detailed studies of the three-dimensional structure of the electron density in the WSA for the period from 2007 till 2013 during the COSMIC experiment showed that the WSA extends over a large region in the south-central Pacific Ocean with a maximum to the west of the southern part of South America (Lin et al., 2009; He et al., 2009; Jee et al., 2009). As part of this experiment, it was shown for 2007 that the effect appears at 22:00 LT from November to February, but is most intense in December and January (Lin et al., 2010). Liu and Yamamoto (2011) showed a weakening of the mid-latitude summer nighttime anomaly during geomagnetic storms.

Concerning the interpretation of WSA, the most likely and strongest factor is the thermospheric wind of the neutral atmosphere (Kohl \& King, 1967; Dudeney \& Piggott, 1978; Chen et al., 2011; Ren et al., 2012). The authors of some studies have suggested that the main reason for the increase in electron density in the nighttime southern ionosphere is the geometry of the geomagnetic field lines (Horvath \& Essex, 2003; Horvath, 2006; He et al., 2009; Chen et al., 2016). Lin et al. (2009) and Knyazeva et al. (2010) noted that the WSA is caused by a significant difference between the geographic and geomagnetic poles. The experimental data were compared with the results of modeling in the frames of modern models (Richards et al., 2017). Jakowski et al. (2015) demonstrated the role of plasma transport between conjugate areas in the formation of ionospheric anomalies.

It should be noted that satellite experiments provide extensive information on the spatial distribution of ionospheric parameters; however, they are seriously limited in time. Satellite experiments in recent years have coincided with low solar activity, which also limits the possibilities for a comprehensive study of WSA using those data.

Richards et al. (2017) note in their conclusions that it would be useful to compare the simulation results with the data of ionospheric sounding from the center of the anomaly, namely from the Argentine Islands, where the ionosonde operated in the second half of the 20 th century. The last comment has partially initiated this article. The fact is that after the transfer of the Faraday station to Ukraine in 1996 the ionosonde was not turned off, it has been operating continuously. Since the ionosonde has been in operation for over 60 years, its data make it possible to analyze the reaction of the ionosphere to solar and geomagnetic activity in a wide range of their values. Thus, processing an unprecedentedly long series of observations can provide valuable information on the processes and mechanisms of interaction between the neutral and ionized components in the Earth's ionosphere. Moreover, provisional comparison of experimental variations of foF2 over Akademik Vernadsky station with estimates obtained using the NeQuick model (Nava et al., 2008) showed a significant discrepancy between them. This fact became one more incentive for a detailed study of WSA using the data of long-term ionospheric sounding at the Akademik Vernadsky station.

This paper aims at analyzing the reaction of the ionosphere during WSA to changes in solar and geomagnetic activity as deduced from the data of vertical sounding of the ionosphere conducted at the Akademik Vernadsky station. It should be emphasized that this interaction is most pronounced on Earth in the WSA region over Argentine Islands. 


\section{Data and methods}

\subsection{Ionospheric sounding} at the Akademik Vernadsky station

As was mentioned earlier, the vertical sounding of the ionosphere (VSI) at the Akademik Vernadsky station has been going on since the late 1950-s. At present two different ionosondes are operating there (Zalizovski et al., 2020). The first one is the IPS-42 ionosonde that has been used since 1982. A new portable Doppler ionosonde (Zalizovski et al., 2018) developed and manufactured in cooperation between the Institute of Radio Astronomy of the National Academy of Sciences of Ukraine (IRA NASU) and the International Centre for Theoretical Physics (ICTP) was installed at Akademik Vernadsky station in April 2017 to support and extend existing ionospheric observations. Thus, since 2017 in addition to traditional ionograms, we have information about Doppler frequency shift (DFS) of reflected signals that permit us to estimate the vertical movement in the ionospheric layers. More detailed information about the joint operation of two ionosondes at the Akademik Vernadsky station as well as the technique of median HT-diagrams building is provided by Zalizovski et al. (2020).

\subsection{Data processing techniques}

Ionospheric parameters at the Akademik Vernadsky station were traditionally estimated from the ionograms manually by an operator. At present software developed by Konstantin Garmash in 2001 during the $6^{\text {th }}$ Ukrainian Antarctic expedition and updated later is used. As a result, text files with values of main ionospheric parameters such as critical frequencies and virtual heights of E, sporadic E (Es), F1, F2 layers, parameter $\mathrm{M}(3000)$ for $\mathrm{F} 1$ and F2 layers, and some comments are accumulated with a time step of 1 hour. After the end of a month the monthly median values of foF2, foEs, and $\mathrm{M}(3000)$ for the F2 layer are calculated and archived.

Median monthly height-time (HT) diagrams are calculated at the Akademik Vernadsky station during the last years for visualizing the dynamics of the ionosphere during the month in one figure. A technique for building the HT-diagrams for Akademik Vernad- sky station ionosondes is also described in (Zalizovski et al., 2020). It should be noted that the HT diagrams for the IPS-42 data rather demonstrate the plasma frequency dynamics for the $\mathrm{X}$ - than $\mathrm{O}$-polarized wave due to the lack of polarization selection in this device. But it is insignificant for the purposes of this study because the variations in the plasma frequencies of both the $\mathrm{O}$ - and $\mathrm{X}$-polarized waves occur synchronously.

We analyze the reaction of the ionosphere to solar and geomagnetic activity by comparison of median foF2 values for the years of low and high solar activity, and by comparison of HT-diagrams calculated for a given month separately for the time intervals characterized by low and high levels of F10.7 index prepared by NOAA, Space Weather Prediction Center (downloaded from: https://services.swpc.noaa. gov/text/daily-solar-indices.txt) and local $\mathrm{K}$ index.

\section{Results and discussion}

\subsection{WSA in foF2 variations}

As was described above, the WSA manifests itself in an inversion of diurnal variation of foF2 in the summer. It could be seen in Figure 1 that the features of foF2 diurnal variations in January are not the same in the years characterized by relatively low (1996-1997, 2006-2008) and high (1999-2002) levels of solar activity. Comparison with the variation of plasma upwelling estimated using the model NRLMSISE-00 (Picone et al., 2002) for the middle of January for quiet and low solar activity respectively demonstrates high level of correlation between the two processes.

\subsection{WSA in HT diagrams}

Figure 2 shows the median value of the plasma frequency presented in colors versus local time (the abscissa) and virtual height (the ordinate) for averaged HT diagrams for Decembers from 2007 till 2016. Ionograms obtained by IPS-42 ionosonde were used for that. One can see that the maximum electron density in the F region was observed near 0200 LT, just after midnight. The virtual height of nighttime maximum in plasma frequency and electron density 


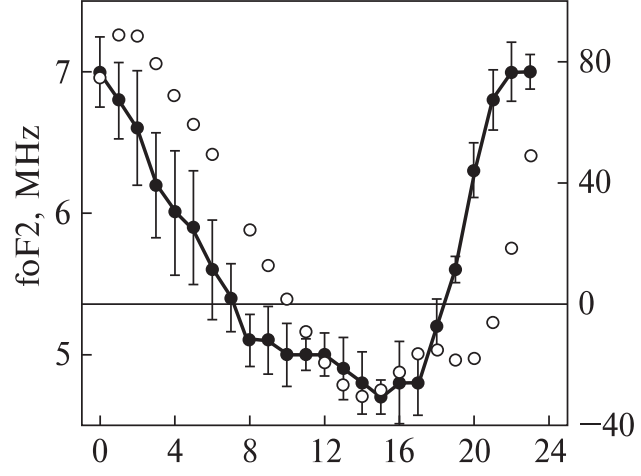

(a)

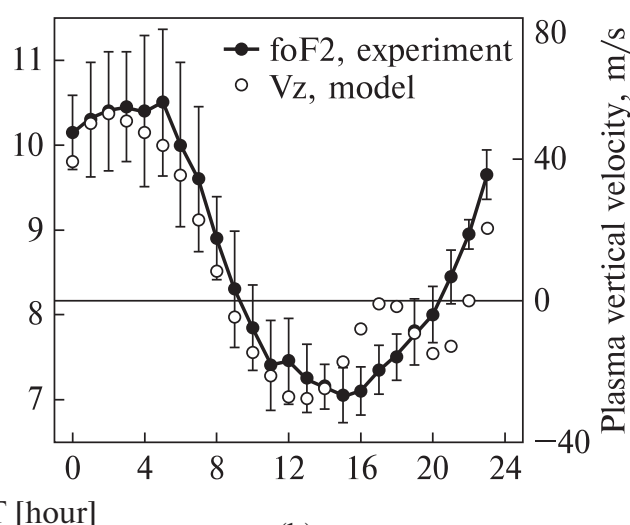

(b)

Figure 1. Variations of median values of foF2 (filled dots with lines) and variations of vertical plasma movement under influence of horizontal wind estimated for the height of $280 \mathrm{~km}$ (empty circles) for Januaries characterized by quiet (a) - 1996-1997, 2006-2008, and high (b) - 1999-2002 solar activity. Error bars show the standard deviations of median values of foF 2 within the averaged years

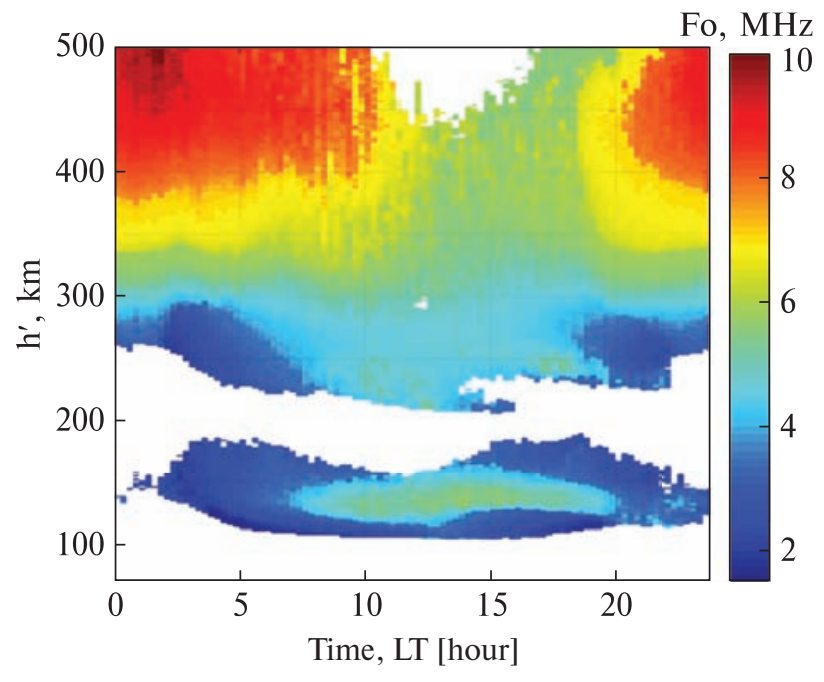

Figure 2. Median height-time charts of plasma frequencies over Akademik Vernadsky station for Decembers 2007-2016

is situated around $500 \mathrm{~km}$, significantly higher than the virtual height of daytime one (around $400 \mathrm{~km}$ ). Dense original and sporadic layers are observed in the E region between 100 and $170 \mathrm{~km}$ (Fig. 2).

Although the WSA depends on plasma vertical transport by thermospheric winds we do not see in December significant vertical velocities in the $F$ region during either nighttime or evening and morning (Fig. 3a). For the nighttime, it could be explained by the dynamic balance between photochemical processes and plasma transport that lead to such a stable and dense F2 layer. As a result, the phase paths of signals reflected from the ionosphere remain stable too, and DFS, in this case, is close to zero. In contrast, for the equinox much bigger vertical speeds are observed downward in the morning and upward in the evening (Fig. 3b).

Dependence of Weddell Sea anomaly features on helio- and geophysical activity is analyzed by comparing the median height-time charts for different levels of flux F10.7 and local K indices calculated at the AIA observatory operating at Akademik Vernadsky station. Note that the local K index for the Akademik Vernadsky location is changed in line with the value of total energy of precipitated particles in the Southern auroral region. The median chart for all datasets (Fig. 2) could be compared with the HT charts for the days with different levels of indices (Figs. 4-6).

The dependence of WSA on geomagnetic indices is illustrated in Figure 4. The structure of averaged WSA (Fig. 2) is reproduced much better under lower geomagnetic activity (Fig. 4a), in comparison with higher one (Fig. 4b). During the geomagnetically disturbed days, the nighttime maximum becomes weaker and blurs in time from 2200 till 0600 LT. Daytime minimum remains around 1500 LT for both low and high levels of geomagnetic disturbances.

Similar data processing was done for the different levels of the solar F10.7 index. The threshold of F10.7 


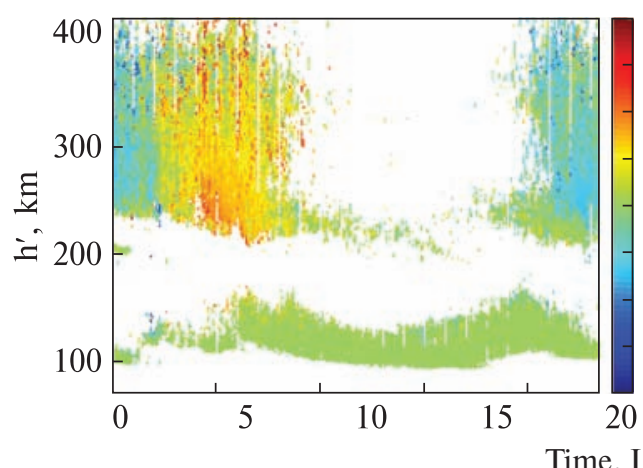

(a)

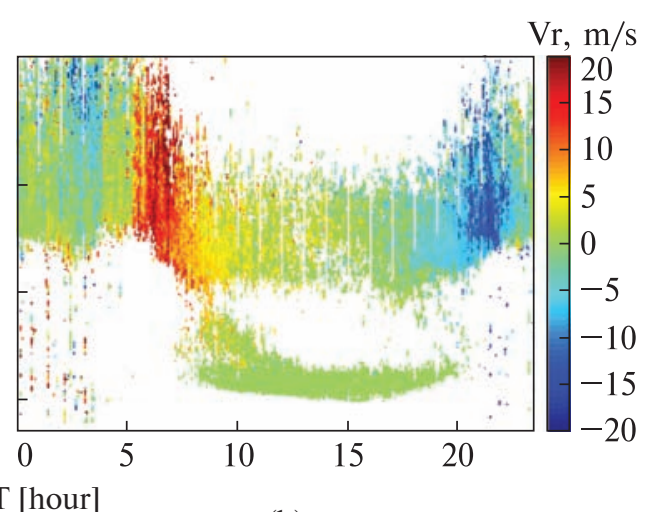

(b)

Figure 3. Median height-time charts of vertical velocities estimated over Akademik Vernadsky station for December 2018 (a) and October 2018 (b). Velocities were calculated using the DFS data of the new coherent ionosonde

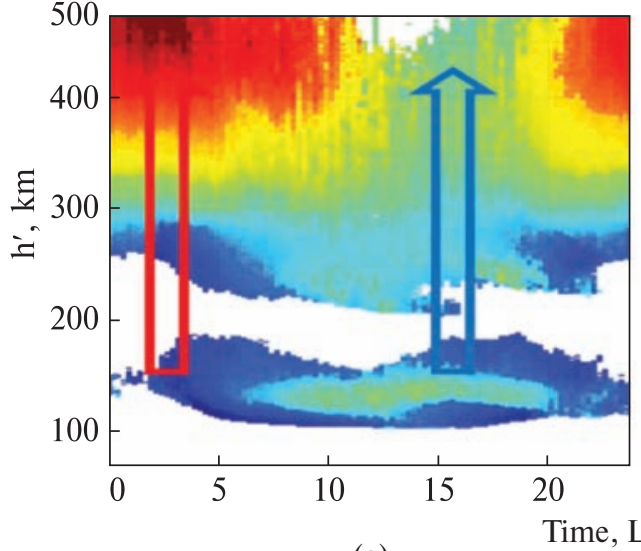

(a)

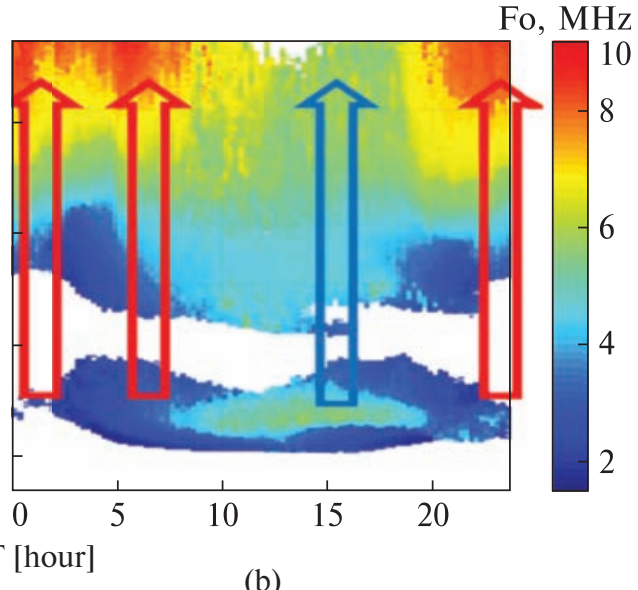

(b)

Figure 4. Median height-time charts of plasma frequencies over Akademik Vernadsky station for Decembers 2007-2016 for the time intervals with K index lower than 2 (a), and higher than 1 (b). Red arrows indicate the time of maximums, blue arrows indicate the time of minimum in diurnal variations of electron density of F2 layer

was established to be 95 because that was the median number for the days of 2007-2016. One can see that the maximum in diurnal variations is shifted exactly to midnight for the low solar ultraviolet flux (Fig. 5a). In contrast, with increasing solar activity and F10.7 index, the nighttime maximum is shifted to the morning and observed around 0300 LT. It could be noted that the visible virtual height of the night maximum is lower for the lower levels of F10.7 (Figs. 5a, 5b).

Due to big sets of processed data (10 years), we can split the sample into 4 arrays by the levels of both in- dices without significant losses in quality of statistics (Fig. 6). As can be seen, the most accurate inversion of diurnal variation of electron density in the $\mathrm{F}$ region is observed under the low values of $\mathrm{K}$ index and low F10.7 flux (Fig. 6a). The biggest nighttime ionization maximum is correspondent to low values of $\mathrm{K}$ index and high values of F10.7 (Fig. 6b). The growth of geomagnetic activity decreases the nighttime ionization under both low (Fig. 6c) and high (Fig. 6d) levels of F10.7 fluxes and leads to blurring of the night maximum. It could be explained by the destruction 


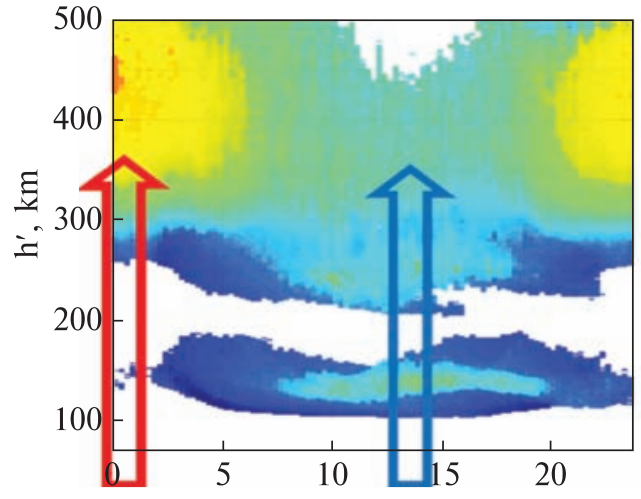

(a)

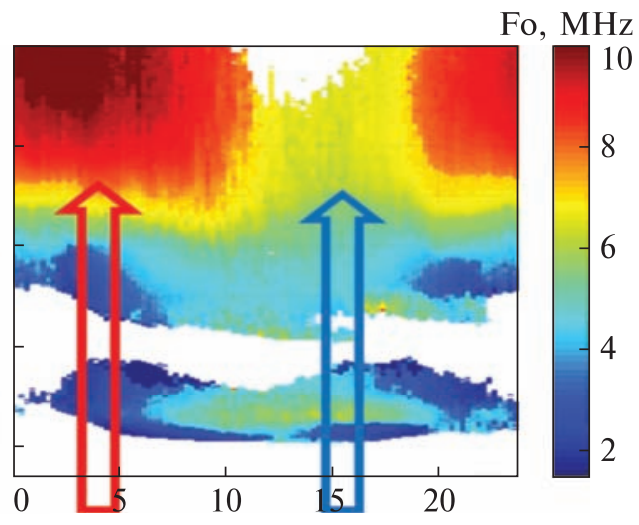

(b)

Figure 5. Median height-time charts of plasma frequencies over Akademik Vernadsky station for Decembers 2007-2016 for the time intervals with F10.7 index lower than 96 (a), and higher than 95 (b). Red arrows indicate the time of maximum, blue arrows indicate the time of minimum in diurnal variations of electron density of F2 layer

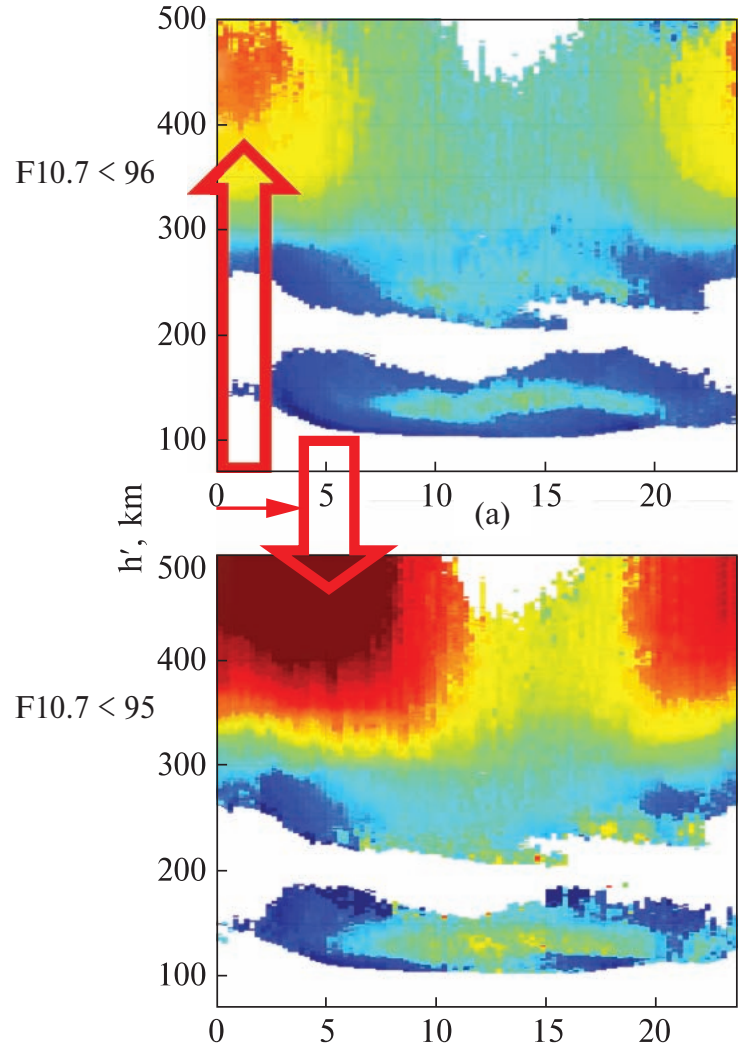

(b)
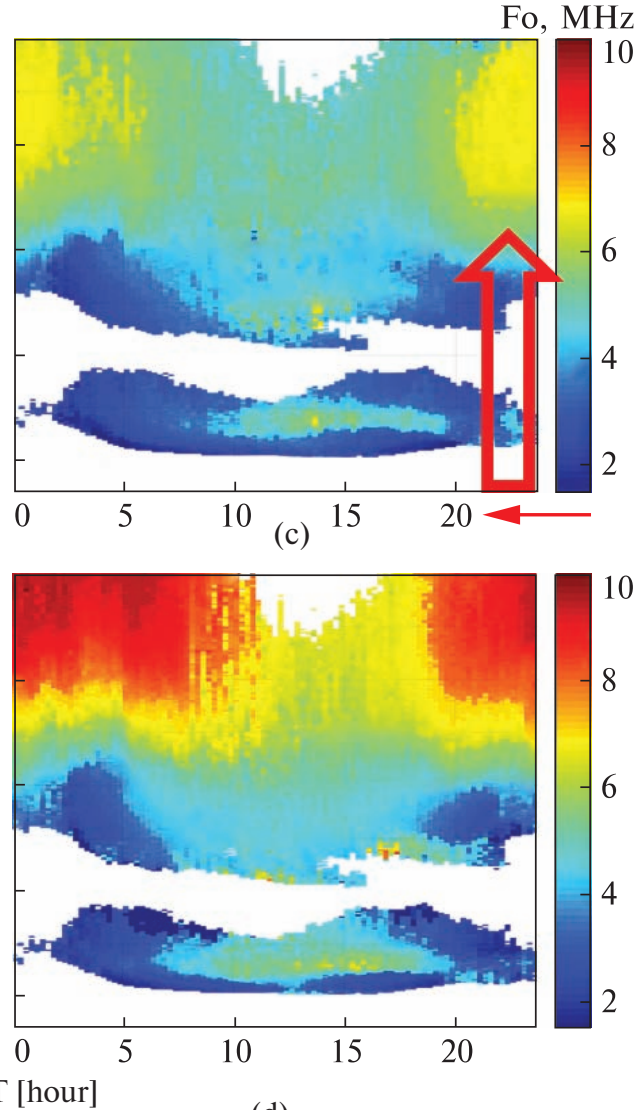

(d)

Figure 6. Median height-time charts of plasma frequencies over Akademik Vernadsky station for Decembers 2007-2016: (a) $\mathrm{K}<2$ and F10.7 < 96; (b) $\mathrm{K}<2$ and F10.7 > 95; (c) $\mathrm{K}>1$ and F10.7 < 96; (d) K > 1; F10.7 $>95$. Red arrows demonstrate the shifts of maximum in comparison with averaged behavior 
of the field of thermospheric winds supporting the nighttime anomaly, and/or by the increasing role of plasma drifts in comparison with wind impact. It seems that under high geomagnetic activity and low F10.7 index the time of a maximum of electron density slightly shifts toward the evening on 2300 LT. Visible virtual heights of maxima increase together with F10.7 independently of K index level.

Let's consider the possible qualitative explanation of the position of nighttime electron density maximum. As known, the cause of the nighttime maximum is the combination of plasma upwelling under the impact of horizontal equatorward thermospheric wind at the area of low geomagnetic field inclination and rate of ionization and recombination. All these factors are grown with UV flux. Temperature and ionization are increased directly by the impact of UV flux. Recombination accelerates due to the growth of the ratio between molecular and atomic components on every height of the F2 region. Understandably, the electron density is growing with F10.7 flux (Figs. 5b, 6a, 6b) because F10.7 is a good indicator of the ionization factor. The dayside temperature, horizontal temperature gradients across the solar terminator, and hence the thermospheric winds are growing too. As a result, the maximum electron density is shifted upward together with the optimal ratio between photochemical and transport balance for accumulating the plasma.

Shifting the maximum electron density in time is not so obvious. Hypothetically, it could be explained by turning the horizontal winds at different heights. Growth of electron density leads to an increase of ion drag force. That can rotate the wind direction which depends on the ratio between pressure and friction forces. As a result, the maximum wind speed projection in the direction of the geomagnetic meridian could be shifted in the diurnal cycle.

\section{Conclusions}

We have demonstrated the dynamics of the ionosphere over Akademik Vernadsky station in presence of Weddell Sea anomaly using averaged HT diagrams. It was shown that the observed Doppler frequency shift of the signals reflected from the ionosphere during night- time in presence of WSA is close to zero. It could be explained a by stable $\mathrm{F} 2$ layer that formed as a result of dynamic equilibrium between photochemical processes and vertical plasma transport. It was experimentally demonstrated that WSA depends on the levels of solar ultraviolet flux and local $\mathrm{K}$ indices. It is shown that the inversion in diurnal variations of electron density manifests itself best under the quiet geomagnetic conditions and is destroyed under the disturbed ones. Maximum of electron densities appears exactly at midnight under low F10.7 and K indices. Growth of solar activity described by the F10.7 index shifts the maximum toward the morning to 0300 0500 LT, whereas increasing $\mathrm{K}$ index leads to a blur of night maximum. That fact can be explained by the destruction of the field of thermospheric winds supporting the nighttime anomaly, and/or by the increasing role of plasma drifts in comparison with wind impact. The visible virtual height of the nighttime maximum grows with increasing solar F10.7 flux. The last fact could be explained by the gain of equatorward thermospheric wind with increasing solar ultraviolet flux that leads to the growth of plasma upwelling effect.

Thus, the formation of WSA is a result of complex interaction between temperature and pressure values, their vertical and horizontal gradients, winds, electron density, and rates of ionization and recombination. The comprehensive analysis of WSA is possible in frames of modern physics-based ionospheric models. That is why the described WSA morphology could be used for calibrating the existing ionospheric models by fitting the model results to the experimental ones.

Author contributions. AZ: The idea, realization, writing. AZ, OC: Illustration preparing. AZ, VL: Data acquisition, preparation, and processing. AZ, IS: Validation, formal analysis, manuscript review, and editing. OC: Literature review, manuscript editing.

Acknowledgments. This paper was partially supported by Partner Project P735 between the European Office of Aerospace Research and Development, the Ukrainian Science and Technology Center, and the Institute of Radio Astronomy, National Academy of Sci- 
ences of Ukraine. The work was partly supported also by Projects "Heliomax" 0119U103575 and 0120U104223 between State Institution National Antarctic Scientific Center and Institute of Radio Astronomy of National Academy of Sciences of Ukraine, and in frames of the budget projects of NASU "Yatagan-3" (№ 0116U000035), "Zond-5" (№ 0119U100354) and "Obstanovka" (№ 0120U100231).

The authors are grateful to colleagues from the Department of Radio Physics of Geospace of the Institute of Radio Astronomy, National Academy of Sciences of Ukraine for the useful comments and discussions of the paper matter.

Conflict of Interest. The authors declare that they have no conflict of interest.

\section{References}

Bellchambers, W. H., \& Piggott, W. R. (1958). Ionospheric measurements made at Halley Bay. Nature, 182, 1596-1597. https://doi.org/10.1038/1821596a0

Chang, L. C., Liu, H., Miyoshi, Y., Chen, C.-H., Chang, F.-Y., Lin, C.-H., Liu, J.-Y., \& Sun, Y.-Y. (2015). Structure and origins of the Weddell Sea Anomaly from tidal and planetary wave signatures in FORMOSAT-3/COSMIC observations and GAIA GCM simulations. Journal of Geophysical Research: Space Physics, 120(2), 1325-1340. https://doi.org/ 10.1002/2014JA020752

Chen, C. H., Huba, J. D., Saito, A., Lin, C. H., \& Liu, J. Y. (2011). Theoretical study of the ionospheric Weddell Sea Anomaly using SAMI2. Journal of Geophysical Research: Space Physics, 116(A4), A04305. https://doi.org/10.1029/2010JA015573

Chen, Y., Liu, L., Le, H., Wan, W., \& Zhang, H. (2016). The global distribution of the dusk-to-nighttime enhancement of summer $\mathrm{N}_{\mathrm{m}} \mathrm{F}_{2}$ at solar minimum. Journal of Geophysical Research: Space Physics, 121(8), 7914-7922. https://doi. org/10.1002/2016JA022670

Dudeney, J. R. \& Piggott, W. R. (1978). Antarctic ionospheric research. Antarctic Research Series, 29, 200-235.

He, M., Liu, L., Wan, W., Ning, B., Zhao, B., Wen, J., Yue, X., \& Le, H. (2009). A study of the Weddell Sea Anomaly observed by FORMOSAT 3/COSMIC. Journal of Geophysical Research: Space Physics, 114(A12), A12309. https://doi.org/10.1029/2009JA014175

Horvath, I. (2006). A total electron content space weather study of the nighttime Weddell Sea Anomaly of 1996/1997 southern summer with TOPEX/Poseidon radar altimetry. Journal of Geophysical Research: Space Physics, 111(A12), A12317. https://doi.org/10.1029/2006JA011679
Horvath, I. \& Essex, E. A. (2003). The Weddell sea anomaly observed with the TOPEX satellite data. Journal of Atmospheric and Solar-Terrestrial Physics, 65(6), 693-706. https://doi.org/10.1016/S1364-6826(03)00083-X

Jakowski, N., Hoque, M. M., Kriegel, M. \& Patidar, V. (2015). The persistence of the NWA effect during the low solar activity period 2007-2009. Journal of Geophysical Research: Space Physics, 120(10), 9148-9160. https://doi.org/ 10.1002/2015JA021600

Jee, G., Burns, A. G., Kim, Y.-H., \& Wang, W. (2009). Seasonal and solar activity variations of the Weddell Sea Anomaly observed in the TOPEX total electron content measurements. Journal of Geophysical Research: Space Physics, 114(A4), A04307. https://doi.org/10.1029/2008JA013801

Knyazeva, M. A., Zubova, Yu. V., \& Namgaladze, A. A. (2010). Numerical modeling of the Weddell Sea Anomaly in behavior of the ionospheric F2-region. Vestnik of MSTU, 13(4/2), 1068-1077. http://vestnik.mstu.edu.ru/show-eng. shtml?art $=1058$ (in Russian)

Kohl, H. \& King, J. W. (1967). Atmospheric winds between 100 and $700 \mathrm{~km}$ and their effects on the ionosphere. Journal of Atmospheric and Terrestrial Physics, 29(9), 1045-1062. https:// doi.org/10.1016/0021-9169(67)90139-0

Lin, C. H., Liu, J. Y., Cheng, C. Z., Chen, C. H., Liu, C. H., Wang, W., Burns, A. G., \& Lei, J. (2009). Three-dimensional ionospheric electron density structure of the Weddell Sea Anomaly. Journal of Geophysical Research: Space Physics, 114(A2), A02312. https://doi.org/10.1029/2008JA013455

Lin, C. H., Liu, C. H., Liu, J. Y., Chen, C. H., Burns, A. G., \& Wang, W. (2010). Midlatitude summer nighttime anomaly of the ionospheric electron density observed by FORMOSAT-3/ COSMIC, Journal of Geophysical Research: Space Physics, 115(A3), A03308. https://doi.org/10.1029/2009JA014084

Liu, H. \& Yamamoto, M. (2011). Weakening of the mid-latitude summer nighttime anomaly during geomagnetic storms. Earth, Planetsand Space, 63, 371-375. https://doi.org/10.5047/ eps.2010.11.012

Nava, B., Coïsson, P., \& Radicella, S. M. (2008). A new version of the NeQuick ionosphere electron density model. Journal of Atmospheric and Solar-Terrestrial Physics, 70(15), 1856-1862. https://doi.org/10.1016/j.jastp.2008.01.015

Picone, J. M., Hedin, A. E., Drob, D. P., \& Aikin, A. C. (2002). NRLMSISE-00 empirical model of the atmosphere: Statistical comparisons and scientific issues. Journal of Geophysical Research: Space Physics, 107(A12), 1468. https://doi. org/10.1029/2002JA009430

Ren, Z., Wan, W., Liu, L., Le, H., \& He, M. (2012). Simulated midlatitude summer nighttime anomaly in realistic geomagnetic fields. Journal of Geophysical Research: Space Physics, 117(A3), A03323. https://doi.org/10.1029/2011JA017010

Richards, P. G., Meier, R. R., Chen, S.-P., Drob, D. P., \& Dandenault, P. (2017). Investigation of the causes of the longitudinal variation of the electron density in the Weddell Sea 
Anomaly. Journal of Geophysical Research: Space Physics, 122(6), 6562-6583. https://doi.org/10.1002/2016JA023565

Zakharenkova, I., Cherniak, I., \& Shagimuratov, I. (2017). Observations of the Weddell Sea Anomaly in the ground-based and space-borne TEC measurements. Journal of Atmospheric and Solar-Terrestrial Physics, 161, 105-117. https://doi.org/ 10.1016/j.jastp.2017.06.014

Zalizovski, A. V., Kashcheyev, A. S., Kashcheyev, S. B., Koloskov, A. V., Lisachenko, V. N., Paznukhov, V. V., Pikulik, I. I., Sopin, A. A., \& Yampolski, Yu. M. (2018). A prototype of a portable coherent ionosonde model. (2018). Space science and technology, 26(3), 10-22. https://doi.org/10.15407/knit 2018.03.010 (in Russian)

Zalizovski, A., Koloskov, O., Kashcheyev, A., Kashcheyev, S., Yampolski, Y., \& Charkina, O. (2020). Doppler vertical sounding of the ionosphere at the Akademik Vernadsky station. Ukrainian Antarctic Journal, 1, 56-68. https://doi.org/10. 33275/1727-7485.1.2020.379

Received: 7 April 2021

Accepted: 4 July 2021

\author{
А. Залізовський ${ }^{1,2,3, *}$, І. Станіславська ${ }^{2}$, В. Лисаченко ${ }^{1}$, O.Чаркіна $^{1}$ \\ ${ }^{1}$ Радіоастрономічний інститут НАН України, м. Харків, 61002, Україна \\ ${ }^{2}$ Центр космічних досліджень Польської академії наук, м. Варшава, 00-716, Польща \\ 3 Державна установа Національний антарктичний науковий центр, \\ МОН України, м. Київ, 01601, Україна
}

* Автор для кореспонденції: zaliz@rian.kharkov.ua

\title{
Мінливість іоносферної аномалії моря Ведделла за даними спостережень на станції «Академік Вернадський»
}

Реферат. Іоносферна аномалія моря Ведделла - це інверсія добової варіації електронної концентрації в іоносфері над Антарктичним півостровом, морем Ведделла та прилеглими територіями, що спостерігається антарктичним літом. Мета роботи полягає в аналізі реакції іоносфери під час аномалії моря Ведделла на зміни сонячної та геомагнітної активності за даними вертикального зондування іоносфери (В3І), що ведеться на Українській антарктичній станції «Академік Вернадський». Мета роботи досягається шляхом порівняння місячних медіанних значень критичних частот іоносфери (foF2) під час аномалії моря Ведделла для років з високою та низькою сонячною активністю, а також порівняння грудневих медіанних висотно-часових діаграм (НТ-діаграм) foF2, розрахованих окремо для періодів 3 низькими та високими рівнями індексу F10.7 та локального К-індексу за 10-річний проміжок часу (2007-2016 рр.). Експериментально показано залежність аномалії від рівнів сонячного індексу F10.7 та локальних К-індексів. Найбільший нічний максимум іонізації відповідає низьким значенням К-індексу та високим значенням F10.7. Найбільш точна інверсія добової варіації концентрації електронів в області F з максимумом опівночі спостерігається за низьких значень K-індексу та низького потоку F10.7. Зростання геомагнітної активності зменшує нічну іонізацію як при низькому, так і при високому рівнях потоків F10.7 і призводить до розмиття нічного максимуму у добовій варіації. Видимі віртуальні висоти максимумів зростають разом із F10.7 незалежно від рівня К-індексу. Розмиття нічного максимуму при зростанні K-індексу можна пояснити руйнуванням поля термосферних вітрів, що підтримують нічну аномалію, та/або збільшенням ролі плазмових дрейфів у порівнянні з впливом вітру. Зростання видимої віртуальної висоти нічного максимуму зі збільшенням потоку F10.7 можна пояснити посиленням термосферного вітру в напрямку екватора, що призводить до посилення ефекту вертикального переносу плазми. Близький до нуля допплерівський зсув частоти сигналів ВЗІ, який спостерігається протягом ночі під час аномалії, можна пояснити стабільністю шару F2, який утворюється в результаті динамічної рівноваги між фотохімічними процесами та висхідним переносом плазми.

Ключові слова: іоносфера, іонограма, аномалія моря Ведделла, медіанна висотно-часова діаграма 